\title{
Biological Weathering and Geochemical Fractionation by Termites: A Case Study of Loessic Sediments from Jawaharlal Nehru University, New Delhi, India
}

\author{
Swati Singh ${ }^{1}$, Anurag Chaudhary ${ }^{1}$, Sumi Handique ${ }^{2}$, Saurabh K. Singh ${ }^{1}$ and \\ Jayant K. Tripathi ${ }^{1^{*}}$ \\ ${ }^{1}$ School of Environmental Sciences, Jawaharlal Nehru University, New Delhi, India \\ 2 Department of Environmental Sciences, Tezpur University, Assam, India \\ *Corresponding Author E-mail: jktrip@yahoo.com
}

\begin{abstract}
Termites are ecosystem engineers who transform soil and sediments and make mounds. They transport and mix large quantities of sediments across the horizons of the mounds, modify their immediate environment at different depths. We have tried to understand the role of termites in weathering and geochemical transformations of homogeneous sediments of termite mounds of Delhi ridge area. The samples and respective parent sediments were collected from the seven locations of Jawaharlal Nehru University, New Delhi. It has been observed that bioturbation of termites caused fining of the mound samples compared to the parent sediments. The mound samples show higher weathering than the parent sediments. Carbonate precipitation in the alkaline conditions imposed by termites could have enriched $\mathrm{Ca}$ and $\mathrm{Mg}$. Whereas, the clay enrichment caused $\mathrm{K}, \mathrm{Al}$ enrichment. Fe got enriched in the oxic condition of mounds. $\mathrm{Ti}$ and $\mathrm{Zr}$ got enriched by the enrichment of finer grains of their minerals already present in the parent material. The enrichment of $\mathrm{Co}, \mathrm{Ni}, \mathrm{Cu}, \mathrm{Cr}$, and $\mathrm{V}$ show the biogeochemical role of the termites. The organic carbon brought by the termites, and iron oxides, both enriched phosphorus in the mounds. It has found that the termite mounds also have potential in sequestering $\mathrm{CO}_{2}$ by accumulating organic matter, precipitating carbonate minerals, and increasing chemical weathering of silicate minerals.
\end{abstract}

Keyword: Termite, Bioturbation, Geochemistry, Weathering, Trace elements

\section{INTRODUCTION}

Termite mounds are earthen nests commonly found all over the tropics and subtropics region of the world. Termites (Isoptera) are the most significant soil ecosystem engineers in the tropics and play a key function in the operation of many tropical and subtropical ecosystems (Bignell, 2006). The functional domain (physical sphere of influence at the point scale) of termite is termed as termitosphere (Lavelle et al., 1997; Dangerfield et al., 1998: Jouquet et al., 2006). Termites build their mounds using aggregates of soil material from several meters depth which 
results in a huge quantity of soil bioturbation (Grassé, 1984). Termites typically (passively) select soil material for feeding, as mound materials are more fine-grained than the surrounding soil (Arshad, 1981; Jouquet et al., 2002; Abe et al., 2009). They also feed on dead plant material (litter) from the surroundings. Through their building and feeding activities, they play a key role in the dynamics of clays and soil organic matter (SOM) in many tropical ecosystems (Jouquet et al., 2007). Numerous studies have been done on the chemical and mineralogical composition of mounds (Semhi et al., 2008; Abe et al., 2009). It has been revealed in some studies that clay minerals in mounds can be dissimilar from those in the adjacent soil (Mahaney et al., 1999; Sako et al., 2009), whereas some other studies did not find any disparity (Jouquet et al., 2005). Therefore, termites play a vital function in nutrient cycling and clay distribution in tropical and subtropical soils (Lee and Wood, 1971; Black and Okwakol, 1997). Termites increase the fertility of soil by increasing the porosity during the process of the mound formation. Termite mounds are also known as nutrient accumulators, which can further increase the fertility of soil when it gets eroded and spread over to the adjacent soil. The nutrient accumulation in the termite mound makes it attractive for geophagy in Africa and some parts of Asia (Klaus and Schmid, 1998; Mills et al., 2009).

Although the termites are important soil fauna and provide important ecological services, they have not received requisite attention. The present study is a contribution to evaluate the effect of termite activities on texture, geochemistry, mineralogy, and organic carbon content of the loessic sediments in the Jawaharlal Nehru campus of New Delhi, India (Tripathi and Rajamani, 1999).

\section{STUDY AREA}

The study area, Jawaharlal Nehru University campus comes under the National capital territory of Delhi (Fig. 1). The JNU campus lies on the plateau of the famous Delhi ridge at an elevation of 250-300 m height above the mean sea level, rising about $100 \mathrm{~m}$ above the adjacent area. The area has a semi-arid climate with most common vegetation as deciduous trees, xerophytic trees and shrubs. The Delhi ridge is an extension of the Aravalli hills, composed of quartzites of the Middle Proterozoic Alwar Group of the Delhi Supergroup (Tripathi and Rajamani, 2003). The aeolian processes associated with the prevailing W to SW winds have been selectively transporting fertile silt materials from the Thar Desert to the Delhi ridge (Tripathi and Rajamani, 1999).

\section{MATERIAL AND METHOD}

For the present study, approximately $2 \mathrm{~kg}$ of termite mound samples and respective parent sediments samples were collected from seven locations on the JNU campus. For termite mound samples (Fig. 2), small chunks were collected from various locations across the mound, which were homogenized to form a representative sample. The respective parent sediments material were collected from a distance of $10 \mathrm{~m}$ from the mound base after removing upper few centimeters layer to avoid any surface contamination. 
Biological Weathering and Geochemical Fractionation by Termites: A Case Study of Loessic Sediments from Jawaharlal Nehru University, New Delhi, India: Singh et al.

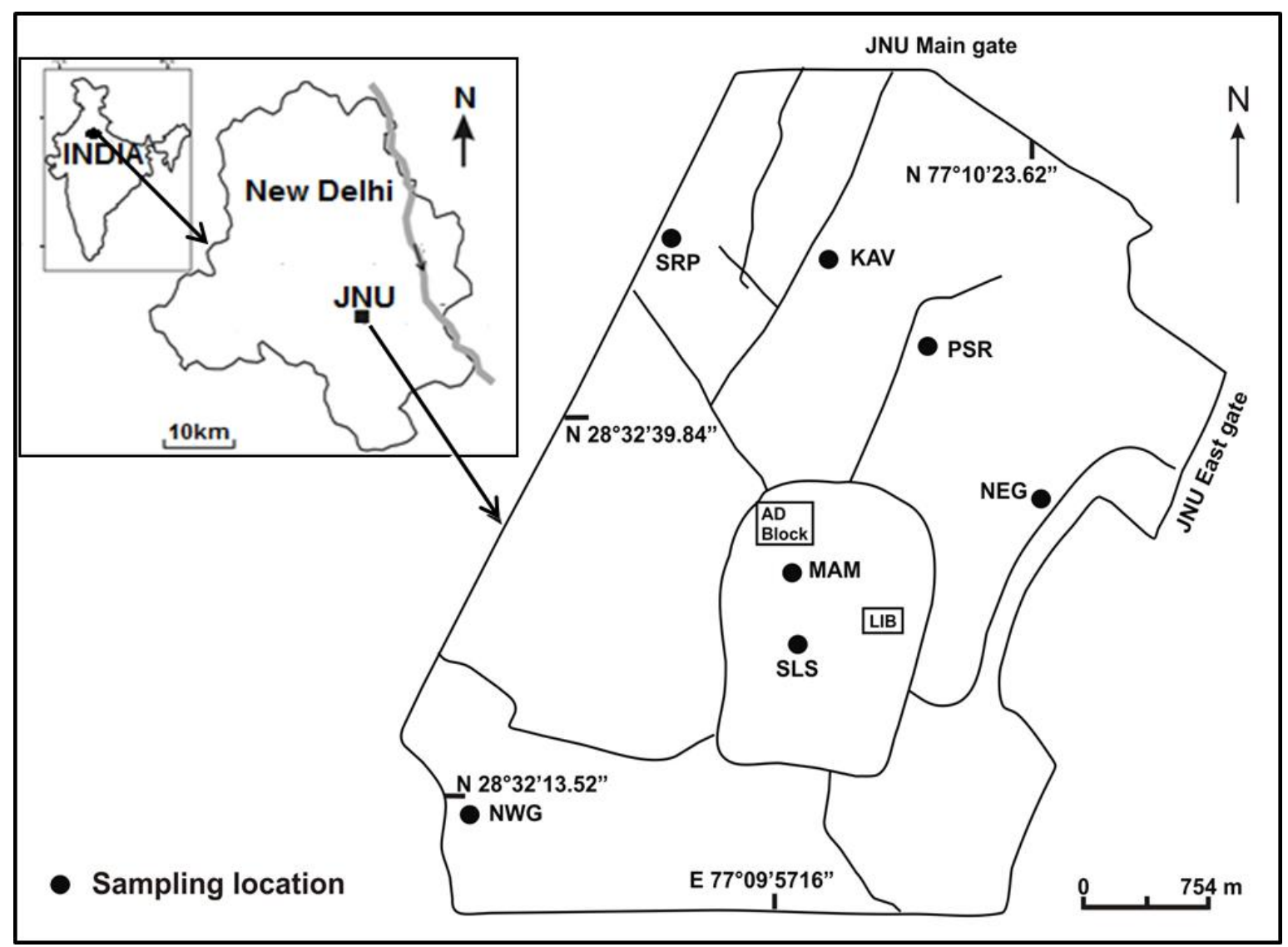

Fig. 1: Sampling locations of the termite mound sediments. The parent material samples were collected from around 10 meters away of the termite mound sediments.

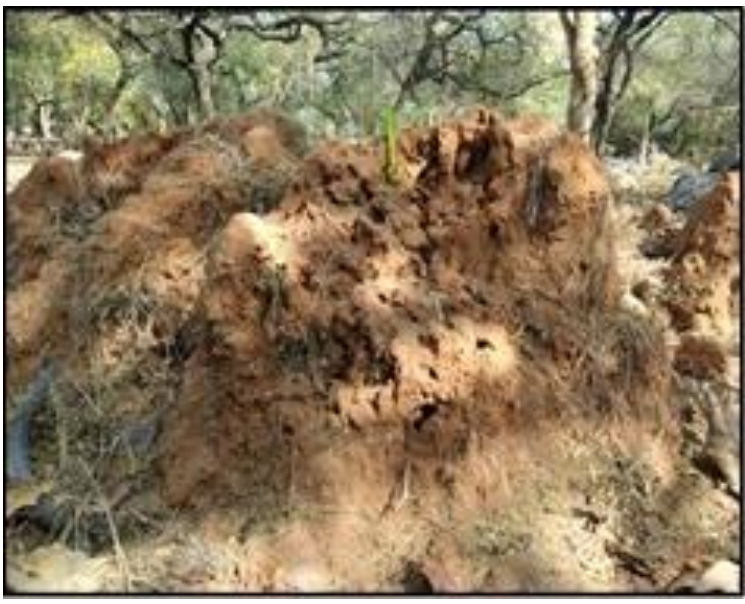

(a)

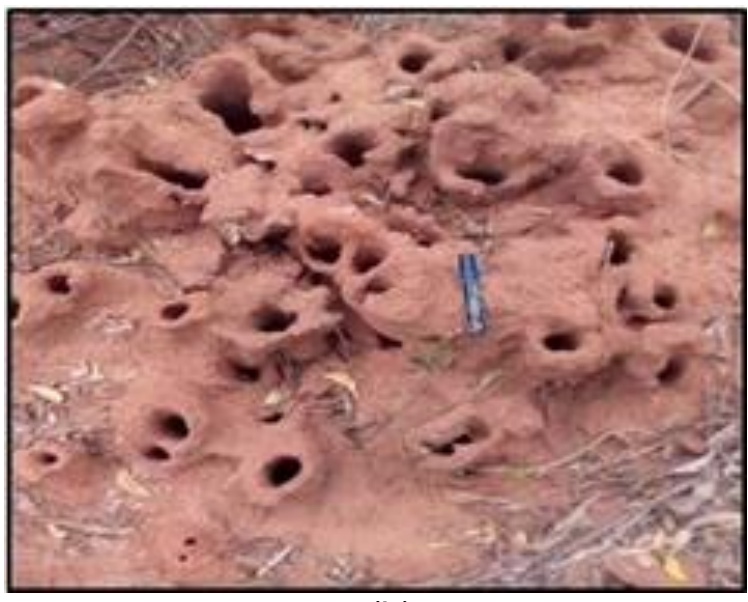

(b)

Fig. 2. Side (a) and top (b) view of termite mounds. 
Biological Weathering and Geochemical Fractionation by Termites: A Case Study of Loessic Sediments from Jawaharlal Nehru University, New Delhi, India: Singh et al.

To determine the texture, the sediment samples were pretreated to deflocculate aggregates by removing carbonate and organic content with $\mathrm{HCl}$ and $\mathrm{H}_{2} \mathrm{O}_{2}$ respectively (Jackson, 1958). The sediment samples were then subjected to wet pipette method to extract finer fraction $(<63 \mu \mathrm{m})$ (Galehouse, 1971; Pandarinath, 2003) using sodium hexmetaphosphate (calgon) as the deflocculater of the clay particles. The dried weight of the samples were used for calculation of percent weight of each size fraction after the correction for the calgon. Dry sieving has been done for the coarser fraction (>63 $\mu \mathrm{m})$ using set of ASTM sieves $(500 \mu \mathrm{m}, 350$ $\mu \mathrm{m}, 250 \mu \mathrm{m}, 171 \mu \mathrm{m}, 125 \mu \mathrm{m}, 88 \mu \mathrm{m}, 63 \mu \mathrm{m}$ and pan).

Homogenized samples $(100 \mathrm{~g})$ were ground to $~ 200$ mesh $(0.72 \mathrm{~mm}$ sieve size) in the agate ball mill for geochemical and mineralogical analysis. The mineralogy of the processed samples was determined using X-ray diffractograms (XRD) obtained from a Philips X'PERT diffractometer. Geochemical analysis of the sediment samples were done by wavelength dispersive X-ray fluorescence (XRF, PANalytical, Axios) for major oxides and trace elements. Pellets $(0.2 \mathrm{~mm}$ thickness and $4 \mathrm{~cm}$ diameter) for the XRF analysis were prepared by thoroughly mixing a few drops of $4 \%$ polyvinyl with $8 \mathrm{gm}$ powered sediments samples in agate pestle. The mixture was then pressed at 2500 psi in pellet holder to form pellets. International standards (BHVO-2, GSP-2, MBH, SDC-1) were routinely run to assess the accuracies of analysis as well as the calibration. The CIA has been calculated after the formula given by Nesbitt and Young (1989) $\quad\left[\mathrm{CIA}=\left(\mathrm{Al}_{2} \mathrm{O}_{3}\right) /\left[\left(\mathrm{Al}_{2} \mathrm{O}_{3}\right)+\left(\mathrm{CaO}^{*}\right)+\left(\mathrm{Na}_{2} \mathrm{O}\right)+\left(\mathrm{K}_{2} \mathrm{O}\right)\right] * 100\right], \quad$ where, $\mathrm{CaO}$ represents $\mathrm{CaO}$ in the silicate fraction only The excess of molar $\mathrm{CaO}$ contributed by $\mathrm{CaCO}_{3}$ minerals has been corrected by taking molar $\mathrm{CaO}$ equal to molar $\mathrm{Na}_{2} \mathrm{O}$ values in the formula (Tripathi et al., 2007).

The organic matter in the sediment samples was estimated by the loss on ignition (LOI) method (Dean, 1974). Sample (1g) weighed in a silica crucible were kept overnight in a muffle furnace to remove moisture. After that, samples were first ignited at $550^{\circ} \mathrm{C}$ for 4 hours to combust organic matter from the sediments as $\mathrm{CO}_{2}$. Organic matter was calculated by using the formula: $L O I_{550}=\left(\left(D W_{550}-D W_{105}\right) / D W_{105}\right) * 100$, where $D W_{105}$ is the dry weight of the sample after heating at $105^{\circ} \mathrm{C}$ and $\mathrm{DW}_{550}$ represents the dry weight of the sample after heating to 550 ${ }^{\circ} \mathrm{C}$ (all in g). TOC was estimated by a procedure developed by Walkely (1947) and revised by Pathak et al. (2013).

\section{RESULT AND DISCUSSION}

The textural analysis of the samples suggests that the parent material of mounts is silty sand sediments; whereas, the termite mound samples are mostly sandy mud (Table-1, Fig. 3). The clay content has been found in higher proportion in the termite mounds than in the adjacent parent materials (Table-1) due to termites' preference for sticky finer soil material (clay rich) which is used as a cementing material for construction of their nests (Lee and Wood, 1971; Donovan et al., 2001). Modifications in soil texture of termite mound samples have been suggested due to the overturning of the soil by the action of termites (Donovan et al., 2001; Jouquet et al., 2002b) in which they easily ingest finer particles. The average bulk mineral compositions of the parent material and termite mound, as estimated from the XRD, do not show any significant variation in their mineral composition. They predominantly consist of quartz, feldspar, muscovite, and chlorite, typical of the silty loessic sediments deposited on the quartzite rocks of JNU campus (Tripathi and Rajamani, 1999). 
Biological Weathering and Geochemical Fractionation by Termites: A Case Study of Loessic Sediments from Jawaharlal Nehru University, New Delhi, India: Singh et al.

Table-1: Textural properties of the termite mound $(T)$ and respective parent material $(P)$

\begin{tabular}{|c|c|c|c|c|c|}
\hline Location & Type & $\begin{array}{c}\text { Coarse } \\
\text { sand }\end{array}$ & $\begin{array}{c}\text { Fine } \\
\text { sand }\end{array}$ & $\begin{array}{c}\text { Silt } \\
\text { (total) }\end{array}$ & Clay \\
\hline \multirow{2}{*}{ NWG } & $\mathrm{T}$ & 7.8 & 10.2 & 62 & 20 \\
& $\mathrm{P}$ & 29.8 & 21.3 & 41.9 & 7 \\
\hline \multirow{2}{*}{ PSR } & $\mathrm{T}$ & 6.2 & 12.8 & 57.3 & 23.7 \\
& $\mathrm{P}$ & 24 & 27.8 & 38.2 & 10 \\
\hline \multirow{2}{*}{ MAM } & $\mathrm{T}$ & 8 & 3.7 & 54.3 & 34 \\
& $\mathrm{P}$ & 23 & 35.1 & 33 & 8.9 \\
\hline \multirow{2}{*}{ KAV } & $\mathrm{T}$ & 13.2 & 15.5 & 47.6 & 23.7 \\
& $\mathrm{P}$ & 27.8 & 28.7 & 36.7 & 6.8 \\
\hline \multirow{2}{*}{ SRP } & $\mathrm{T}$ & 5.4 & 9.6 & 48 & 37 \\
& $\mathrm{P}$ & 30.6 & 22.1 & 34.2 & 13.1 \\
\hline \multirow{2}{*}{ SLS } & $\mathrm{T}$ & 5 & 9.8 & 51.3 & 33.9 \\
& $\mathrm{P}$ & 22 & 29.4 & 37.9 & 10.7 \\
\hline \multirow{2}{*}{ NEG } & $\mathrm{T}$ & 9.6 & 10.5 & 51.2 & 28.7 \\
\cline { 2 - 6 } & $\mathrm{P}$ & 17.6 & 29.2 & 38 & 15.2 \\
\hline
\end{tabular}

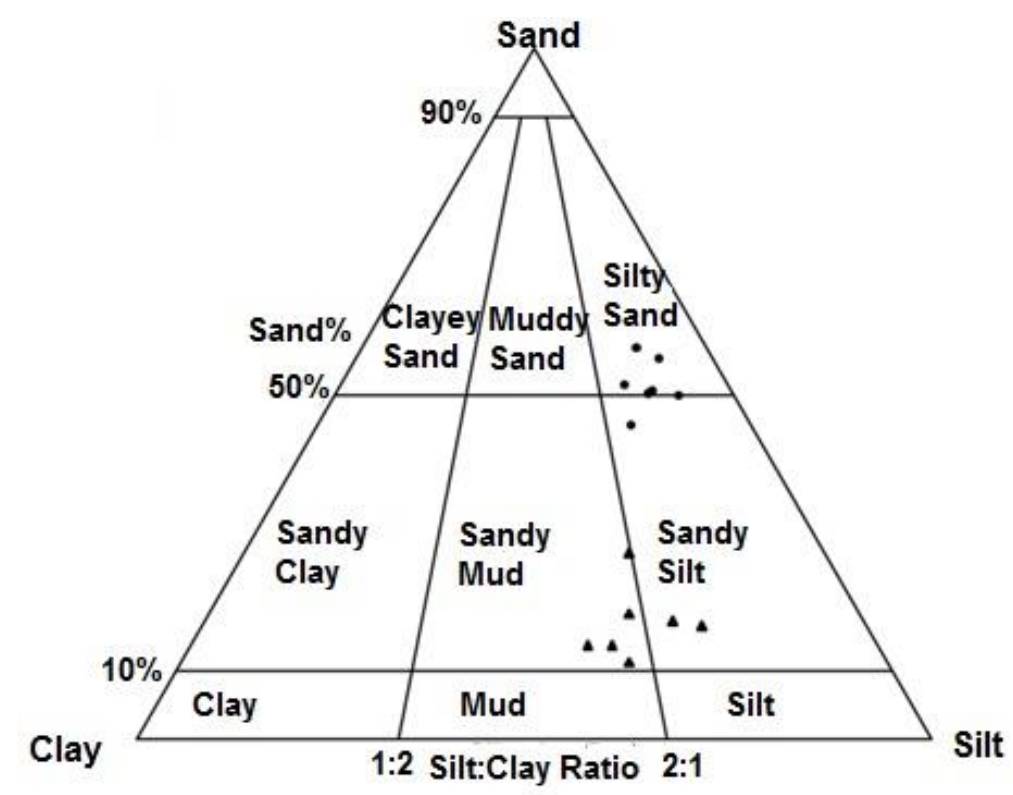

Fig. 3: Ternary diagram showing grain size distribution of the parent sediment samples $(\bullet)$ and termite mound samples ( $\bullet$ ). 
Biological Weathering and Geochemical Fractionation by Termites: A Case Study of Loessic Sediments from Jawaharlal Nehru University, New Delhi, India: Singh et al.

In general termite mound samples have higher organic matter and total organic carbon as compared to the respective parent sediments (Table-2). These are found to be 2-4 times enriched in the termite mound samples than the parent soil. The termites cause bioturbation of the soil during the mound formation. They ingest upon the soil particles which pass through their gut, thereby increasing the organic matter content of the soils. The increase in the organic matter could also be the results of the fecal matter deposit of the termites on the mound. Also, the fecal matter is used by many species of the termites as cementing material along with the clays for the mound formation. The termites also feed on the litter thereby decomposing and which in turn increases the concentration of the organic matter in the mound samples (Holt and Lepage, 2000; Harry et al., 2001).

Table-2: Organic matter, total organic carbon, and CIA (all in \%) of the termite mound sample $(\mathrm{T})$ and respective parent material $(\mathrm{P})$.

\begin{tabular}{|ccccc|}
\hline Location & Type & OM & TOC & CIA \\
\hline \multirow{2}{*}{ NWG } & $\mathrm{T}$ & 8.2 & 4.2 & 74.0 \\
& $\mathrm{P}$ & 2.2 & 1.0 & 64.9 \\
\hline \multirow{2}{*}{ PSR } & $\mathrm{T}$ & 5.8 & 2.8 & 77.1 \\
& $\mathrm{P}$ & 2.4 & 1.1 & 62.0 \\
\hline \multirow{2}{*}{ MAM } & $\mathrm{T}$ & 6.6 & 3.5 & 80.7 \\
& $\mathrm{P}$ & 2.0 & 0.9 & 66.4 \\
\hline \multirow{2}{*}{ KAV } & $\mathrm{T}$ & 4.4 & 2.4 & 76.3 \\
& $\mathrm{P}$ & 1.5 & 0.7 & 68.8 \\
\hline \multirow{2}{*}{ SRP } & $\mathrm{T}$ & 6.2 & 3.5 & 79.3 \\
& $\mathrm{P}$ & 2.4 & 1.1 & 72.0 \\
\hline \multirow{2}{*}{ SLS } & $\mathrm{T}$ & 5.5 & 2.6 & 75.7 \\
& $\mathrm{P}$ & 2.8 & 1.3 & 71.7 \\
\hline \multirow{2}{*}{ NEG } & $\mathrm{T}$ & 7.4 & 3.6 & 76.4 \\
& $\mathrm{P}$ & 3.4 & 1.5 & 70.4 \\
\hline \multirow{2}{*}{ N } & & & &
\end{tabular}

Major element oxide compositions of the samples used in the present study for the termite mound and respective parent material is given in Table-3. The parent samples show high silica values, i.e., $67.81-78.08 \%$, as shown by the high quartz proportions. Whereas, the respective termite mound samples show the relatively lower concentration of silica, i.e., $56.35-61.60 \%$. Similarly, $\mathrm{Na}_{2} \mathrm{O}(0.82 \%-1.44 \%)$ shows higher concentration in the parent material as compared to the termite mound samples. $\mathrm{TiO}_{2}$ concentration was found to be in the range of $0.5-0.9 \%$ in the parent sediment, whereas it was found to be in the range 0.81 to $1.06 \%$ in the termite mound samples. Iron oxide, $\mathrm{FeO}$ was found to vary between 3.38 and 4.67 in the parent material and between 4.71 and $5.81 \%$ in the termite mounds. Exchangeable cations such as $\mathrm{Ca}, \mathrm{Mg}$ and $\mathrm{K}$ are also present in higher concentrations in the mound samples. 
Biological Weathering and Geochemical Fractionation by Termites: A Case Study of Loessic Sediments from Jawaharlal Nehru University, New Delhi, India: Singh et al.

Table-3: Major oxides (\%) and trace elements (ppm) chemistry of termite mound sample (T) and respective parent material $(P)$

\begin{tabular}{|c|c|c|c|c|c|c|c|c|c|c|c|c|c|c|}
\hline & \multicolumn{2}{|c|}{ NWG } & \multicolumn{2}{|c|}{ PSR } & \multicolumn{2}{|c|}{ MAM } & \multicolumn{2}{|c|}{ KAV } & \multicolumn{2}{|c|}{ SRP } & \multicolumn{2}{|c|}{ SLS } & \multicolumn{2}{|c|}{ NEG } \\
\hline & $T$ & $\mathbf{P}$ & $T$ & $\mathbf{P}$ & $T$ & $\mathbf{P}$ & $T$ & $\mathbf{P}$ & $T$ & $\mathbf{P}$ & $T$ & $\mathbf{P}$ & $T$ & $\mathbf{P}$ \\
\hline $\mathrm{SiO}_{2}$ & 60.6 & 75.1 & 56.4 & 70.8 & 59.0 & 78.1 & 61.5 & 69.4 & 58.4 & 69.5 & 61.6 & 69.2 & 58.5 & 67.8 \\
\hline $\mathrm{TiO}_{2}$ & 0.8 & 0.6 & 1.1 & 0.6 & 1.0 & 0.5 & 1.0 & 0.9 & 1.0 & 1.1 & 0.9 & 0.9 & 1.1 & 0.8 \\
\hline $\mathrm{Al}_{2} \mathrm{O}_{3}$ & 15.3 & 10.8 & 17.7 & 11.2 & 18.6 & 8.0 & 17.2 & 14.3 & 18.7 & 12.9 & 17.3 & 13.8 & 16.1 & 13.7 \\
\hline $\mathrm{FeO}$ & 4.7 & 3.1 & 5.4 & 3.3 & 5.8 & 3.4 & 5.6 & 3.5 & 5.3 & 3.4 & 5.6 & 3.6 & 5.7 & 4.7 \\
\hline MnO & 0.1 & 0.1 & 0.1 & 0.1 & 0.1 & 0.0 & 0.1 & 0.1 & 0.1 & 0.1 & 0.1 & 0.1 & 0.1 & 0.1 \\
\hline MgO & 2.3 & 1.8 & 2.3 & 1.9 & 1.9 & 1.3 & 1.7 & 1.5 & 2.8 & 1.8 & 2.5 & 2.1 & 2.9 & 1.8 \\
\hline $\mathrm{CaO}$ & 2.4 & 1.9 & 5.5 & 2.9 & 1.8 & 1.4 & 1.4 & 0.9 & 2.2 & 1.5 & 2.1 & 1.4 & 3.2 & 2.0 \\
\hline $\mathrm{Na}_{2} \mathrm{O}$ & 0.9 & 1.2 & 0.8 & 1.4 & 0.7 & 1.2 & 0.7 & 0.9 & 0.7 & 0.8 & 0.8 & 1.0 & 0.8 & 1.0 \\
\hline $\mathrm{K}_{2} \mathrm{O}$ & 2.2 & 1.7 & 2.3 & 2.0 & 2.0 & 1.3 & 2.8 & 2.1 & 2.7 & 2.4 & 2.2 & 2.1 & 2.2 & 1.9 \\
\hline $\mathrm{P}_{2} \mathrm{O}_{5}$ & 0.16 & 0.12 & 0.16 & 0.13 & 0.13 & 0.1 & 0.17 & 0.14 & 0.22 & 0.17 & 0.21 & 0.15 & 0.18 & 0.15 \\
\hline $\mathrm{Ba}$ & 330 & 209 & 399 & 236 & 378 & 197 & 357 & 241 & 332 & 263 & 287 & 236 & 392 & 266 \\
\hline Sc & 11 & 8 & 17 & 8 & 15 & 5 & 16 & 13 & 17 & 15 & 11 & 6 & 14 & 13 \\
\hline v & 94 & 66 & 124 & 65 & 122 & 54 & 116 & 82 & 132 & 104 & 148 & 106 & 122 & 96 \\
\hline $\mathrm{Cr}$ & 103 & 70 & 136 & 67 & 135 & 70 & 122 & 91 & 128 & 103 & 138 & 109 & 135 & 116 \\
\hline Co & 12 & 3 & 15 & 4 & 18 & 3 & 13 & 11 & 16 & 6 & 13 & 6 & 12 & 4 \\
\hline $\mathbf{N i}$ & 51 & 37 & 62 & 35 & 69 & 27 & 82 & 53 & 94 & 83 & 91 & 74 & 83 & 54 \\
\hline $\mathrm{Cu}$ & 33 & 27 & 29 & 15 & 32 & 21 & 41 & 27 & 46 & 31 & 50 & 33 & 42 & 19 \\
\hline $\mathrm{Zn}$ & 82 & 73 & 75 & 65 & 75 & 69 & 97 & 82 & 98 & 86 & 147 & 126 & 87 & 78 \\
\hline $\mathbf{R b}$ & 110 & 94 & 112 & 96 & 106 & 74 & 97 & 113 & 127 & 136 & 110 & 110 & 109 & 102 \\
\hline $\mathrm{Sr}$ & 182 & 158 & 211 & 184 & 147 & 126 & 156 & 134 & 146 & 128 & 183 & 164 & 205 & 179 \\
\hline $\mathrm{Zr}$ & 457 & 400 & 549 & 352 & 506 & 439 & 582 & 511 & 452 & 455 & 538 & 410 & 596 & 414 \\
\hline
\end{tabular}

A total of 11 trace elements were analyzed in the termite mound samples as well as the respective parent samples. Almost all the elements in the mound samples are found to be present in a higher concentration as compared to the respective parent material (Table-3). Ba in the parent soil ranged between 197 ppm and 263 ppm whereas in the mound samples it was found to vary from 287 ppm to 399 ppm. Trace elements such as $\mathrm{Co}, \mathrm{Cu}, \mathrm{Ni}$ and $\mathrm{V}$ are found to show maximum variation. Cobalt in the mound samples varies between 12 and $18 \mathrm{ppm}$ whereas in the parent soil is ranges from 3 to $6 \mathrm{ppm}$. The concentration of copper in the termite mound samples are found to range between $29 \mathrm{ppm}$ and $50 \mathrm{ppm}$ while in the parent soil samples it varies between 15 and $33 \mathrm{ppm}$. The nickel concentration in the mound samples is found to vary between 51 and $94 \mathrm{ppm}$ whereas in the parent sediments it has been found in the range of $27 \mathrm{ppm}$ and $84 \mathrm{ppm}$. 
Biological Weathering and Geochemical Fractionation by Termites: A Case Study of Loessic Sediments from Jawaharlal Nehru University, New Delhi, India: Singh et al.

The CIA values of the parent sediment samples have been found to range between 62 and $72 \%$ with an average of $68 \%$. The CIA of the termite mound samples varies between 74 and $81 \%$ with an average value of $77 \%$. This indicates that the termite mound samples contain minerals with the higher degree of chemical weathering as compared to the respective parent material samples. For the mound formation termites bring finer particles with the higher CIA from the adjacent. Also, these particles pass through the gut of termite which results in the further breakdown and geochemical changes. It is very difficult here to assign the extent of weathering occurred in the guts of termites. The molar proportions of $\mathrm{Al}_{2} \mathrm{O}_{3}, \mathrm{CaO}+\mathrm{Na}_{2} \mathrm{O}+\mathrm{K}_{2} \mathrm{O}$; and $\mathrm{Al}_{2} \mathrm{O}_{3}$, $\mathrm{CaO}+\mathrm{Na}_{2} \mathrm{O}+\mathrm{K}_{2} \mathrm{O}$ and $\mathrm{FeO}+\mathrm{MgO}$ are plotted on triangular plots, i.e., A-CN-K and A-CNK-FM, separately (Nesbitt and Young, 1984, 1989) (Fig. 4). The parent material samples plot in the relatively less weathered region of the $\mathrm{A}-\mathrm{CN}-\mathrm{K}$ ternary diagram, and the parent, as well as mound samples both plot parallel to the 'A-CN' line. The termite mound samples plot above the parent material, towards the A apex. In the A-CNK-FM diagram, the samples show slight enrichment of FM component. To understand the enrichment of various elements (major and trace elements) in the termite mound samples, their elemental values were normalized with the values of the respective parent material samples (Fig. 5).

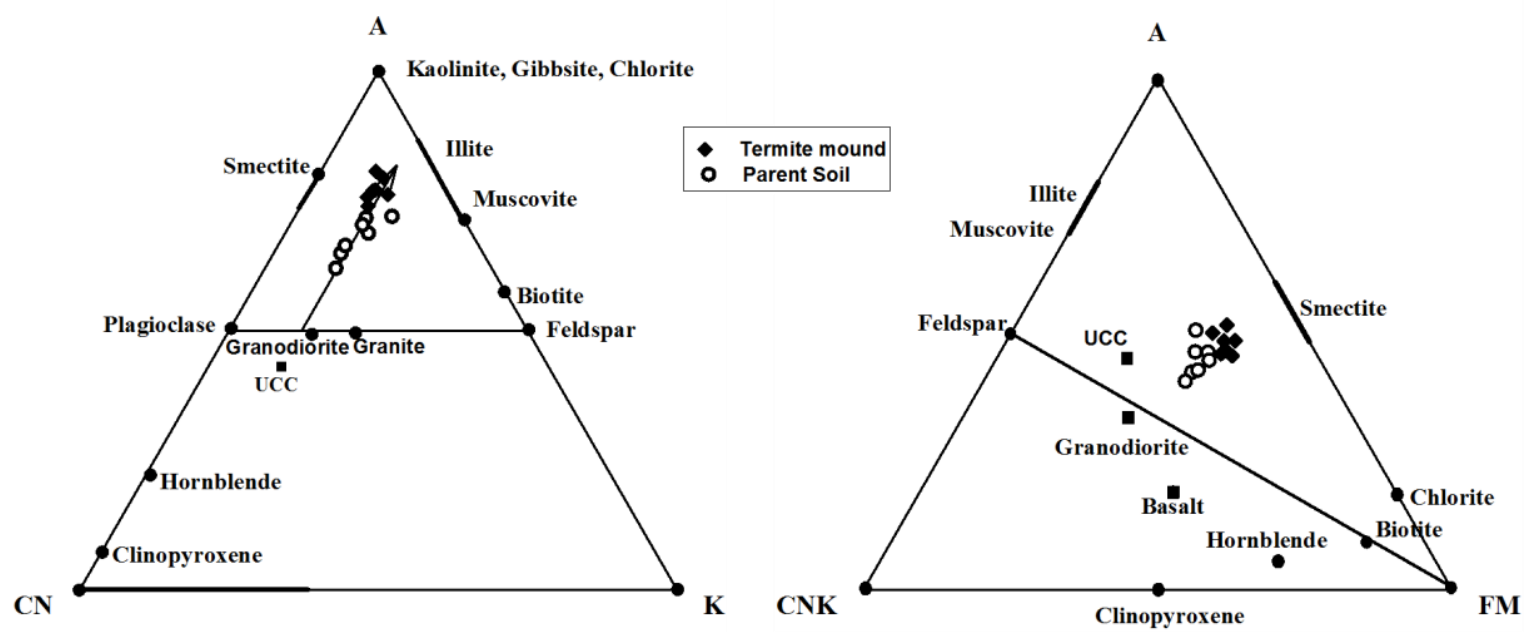

Fig. 4: $\mathrm{A}-\mathrm{CN}-\mathrm{K}$ and $\mathrm{A}-\mathrm{CNK}-\mathrm{FM}$ plots for parent material and termite mounds. A-CN-K plot suggests that termite mound samples exhibit a higher degree of weathering (a), A-CNKFM plot indicates slight enrichment in FM content (b).

A significant loss of $\mathrm{Na}$ has been observed during weathering and formation of termite mound soil. Mounds have been found enriched in exchangeable basic cations, especially $\mathrm{Ca}$ and $\mathrm{Mg}$, due to the presence of their carbonates precipitated during evaporation of water in the porous mounds sediments. Similar precipitations were also observed by others (Watson, 1975; Jouquet et al., 2005; Abe et al., 2009; Mujinya et al., 2010, 2011). The high pH for the precipitation is maintained by the termites in the mounds as soil particles probably undergo modifications through their gut because of the extremely alkaline $\mathrm{pH}$, reaching values up to 12 (Brune and Kühl, 1999; Brauman, 2000; Ohkuma, 2003). Al and K show a greater enrichment during the formation of termite mounds, which is in agreement with the increase in the clay content of the termite mounds as compared to the respective parent samples. The greater enrichment of these elements could be possible because of fractionation of micaceous minerals to the mounds while bringing the finer sediments to the mounds by the termites. 
Biological Weathering and Geochemical Fractionation by Termites: A Case Study of Loessic Sediments from Jawaharlal Nehru University, New Delhi, India: Singh et al.


Fig. 5: Parent soil log normalized diagram indicates enrichment of various elements in the termite mounds.

The enrichment in the Fe concentration could be due to the formation of iron oxyhydroxides during the mound formation, which is responsible for reddening of the mounds sediments. The depletion of silica in the termite mound samples is the result of the decrease in the coarser fraction, i.e., sand enriched in quartz. The increase in the concentration of phosphorus in the termite mound samples against the respective parent material could be due to the high organic matter content in the termite mound samples as well as the increase in the iron oxide concentration. They both get enriched in phosphorus, first one being available and second one being unavailable forms (Mishra et al., 2013). Termite mound also shows enrichment of various trace and nutrient elements such as $\mathrm{Ba}, \mathrm{V}, \mathrm{Co}, \mathrm{Cu}, \mathrm{Ni}, \mathrm{Zn}$ and $\mathrm{Zr}$. Nutrient enrichment in the mounds samples could be due to the enrichment of organic matter by the activity of termites in 
Biological Weathering and Geochemical Fractionation by Termites: A Case Study of Loessic Sediments from Jawaharlal Nehru University, New Delhi, India: Singh et al.

the mound and preferential selection of fine soil particles (Liu et al., 2007; Mills et al., 2009). Organic matter and clays provide adsorption sites for metal which could be the reason for the enrichment of major and trace elements (Fig. 6 and 7).


Clay (\%)

Clay (\%)

\section{Clay (\%)}

Fig. 6: Variation digrams of various elements with clay percent.

Also, many trace elements such as $\mathrm{Co}, \mathrm{Ni}, \mathrm{Cu}, \mathrm{Zn}$ are found in metalloproteins which are vital for the metabolic processes (Frausto da Silva and Williams, 2001). Co is a key requirement for gut bacteria in the termites (Milewski and Diamond, 2000). $\mathrm{Ti}$ and $\mathrm{Zr}$ seem to have concentrated due to depletion of silica rich coarser grains (e.g., quartz), and in a result relative increase in the silt size $\mathrm{Ti}$ and $\mathrm{Zr}$ phases of the sediments (Tripathi and Rajamani, 1999).

\section{CONCLUSION}

The observations from the present study on the termite mound samples suggest that (1) bioturbation caused by the action of termite results in the fining of the soils samples compared to the adjacent parent sediment samples, (2) the termite mound soil samples have been found more weathered in nature than the parent sediments samples, (3) the mound samples are found to be enriched in the exchangeable bases, such as $\mathrm{Ca}, \mathrm{Mg}$, by carbonate precipitation, $\mathrm{K}$ and $\mathrm{Al}$ by the clay/micaceous enrichment, and other major elements such as Fe by iron oxide precipitation in the porous aerated mounds, (4) the mound samples are found to be enriched in the trace 
Biological Weathering and Geochemical Fractionation by Termites: A Case Study of Loessic Sediments from Jawaharlal Nehru University, New Delhi, India: Singh et al.

elements with the highest enrichment for $\mathrm{Co}, \mathrm{Ni}, \mathrm{Cu}, \mathrm{Cr}$ and $\mathrm{V}$ possibly due to higher clay and organic matter concentration in the mound samples, where termite may have played their biogeochemical role, (5) the organic carbon and iron oxides are responsible for the enrichment of phosphorus in the mounds as available and unavailable forms, respectively, and (6) the increased organic matter, higher weathering index and precipitation of carbonates, all indicate potential of termites in the $\mathrm{CO}_{2}$ sequestration.
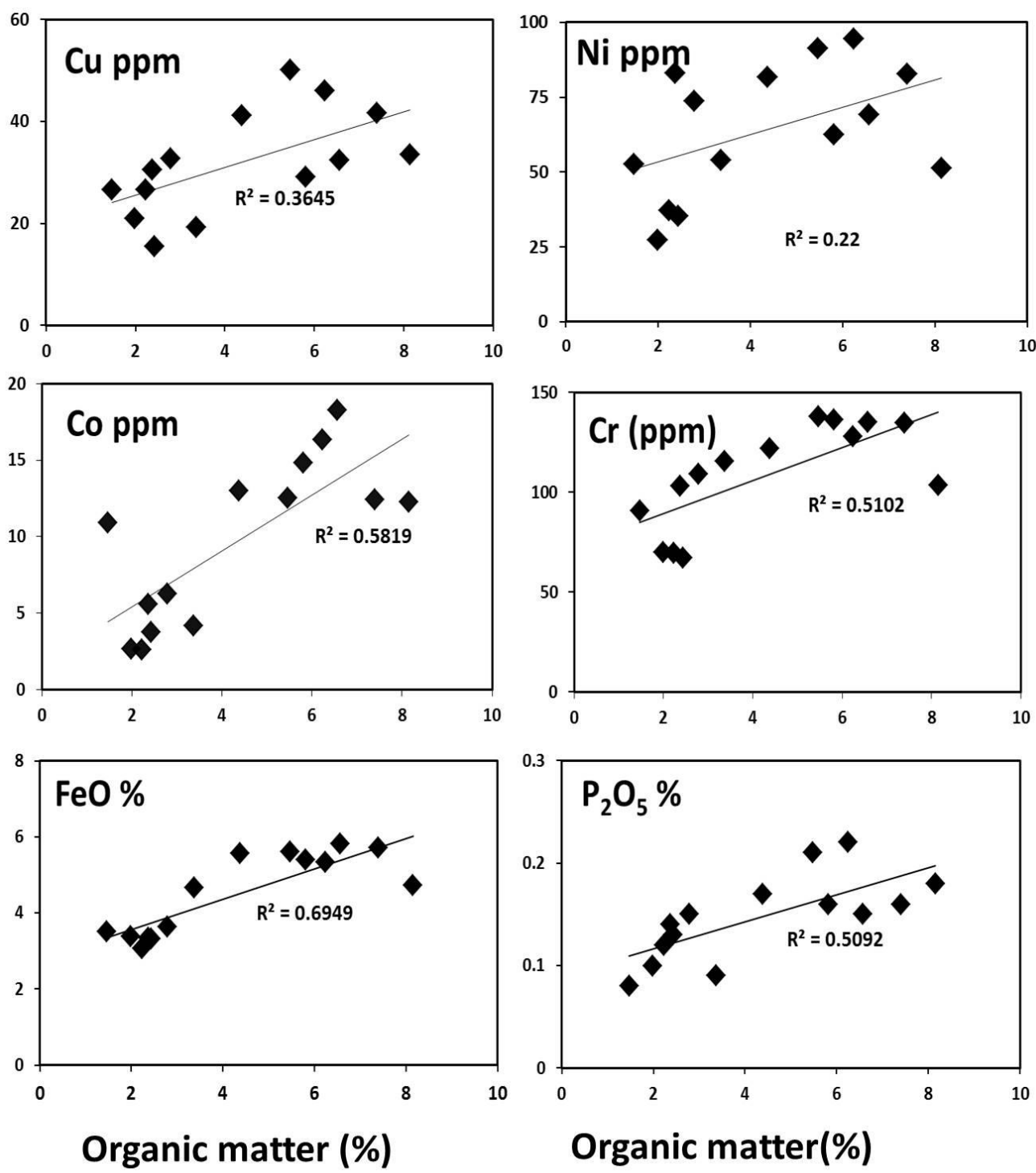

Fig. 7: Variation digrams of various elements with organic matter content.

Acknowledgement: SS acknowledges Council of Scientific and Industrial Research (CSIR) for a research fellowship. JKT acknowledges the Department of Science and Technology (DST), India for the DST- 
Biological Weathering and Geochemical Fractionation by Termites: A Case Study of Loessic Sediments from Jawaharlal Nehru University, New Delhi, India: Singh et al.

PURSE research grants to Jawaharlal Nehru University. Authors duly acknowledge the reviewer and the editor.

\section{REFERENCES}

Abe, S. S., Yamamoto, S. and Wakatsuki, T. (2009) Soil-particle selection by the mound-building termite Macrotermes bellicosus on a sandy loam soil catena in a Nigerian tropical savanna. Journal of Tropical Ecology, v. 25(04), pp.449-452.

Arshad, M.A. (1981) Physical and chemical properties of termite mounds of two species of Macrotermes (Isoptera, Termitidae) and the surrounding soil of the semiarid savannah of Kenya. Soil Science, v. 132(2), pp.161-174.

Bignell, D.E. (2006) Termites as soil engineers and soil processors. In: A. Koing and A. Varma (eds.) Intestinal microorganisms of termites and other invertebrates. Springer Berlin Heidelberg. pp. $183-220$

Black, H.I.J. and Okwakol, M.J.N. (1997) Agricultural intensification, soil biodiversity and agroecosystem function in the tropics: the role of termites. Applied Soil Ecology, v. 6(1), pp.37-53.

Brauman, A. (2000) Effect of gut transit and mound deposit on soil organic matter transformations in the soil feeding termite: a review. European Journal of Soil Biology, v. 36(3), pp.117-125.

Brune, A. and Kühl, M. (1996) pH profiles of the extremely alkaline hindguts of soil-feeding termites (Isoptera: Termitidae) determined with microelectrodes. Journal of Insect Physiology, v. 42(11-12), pp.1121-1127.

Da Silva, J.F. and Williams, R.J.P. (2001) The biological chemistry of the elements: the inorganic chemistry of life. Oxford University Press.

Dangerfield, J.M., McCarthy, T.S. and Ellery, W.N. (1998) The mound-building termite Macrotermes michaelseni as an ecosystem engineer. Journal of Tropical Ecology, v. 14(04), pp. 507-520.

Dean Jr, W.E. (1974) Determination of carbonate and organic matter in calcareous sediments and sedimentary rocks by loss on ignition: comparison with other methods. Journal of Sedimentary Research, v. 44(1), pp.

Donovan, S.E., Eggleton, P. and Bignell, D.E. (2001) Gut content analysis and a new feeding group classification of termites. Ecological Entomology, v. 26(4), pp. 356-366.

Galehouse, J.S. (1971) Sedimentation analysis. In: R.E Carver (ed.) Procedures in Sedimentary Petrology, Wiley-Interscience, New York, pp. 69-94.

Grassé, P.P. (1984) Termitology. Termite anatomy-physiology-biology-systematics. Vol. II. Colony foundation-construction. Masson.

Harry, M., Jusseaume, N., Gambier, B. and Garnier-Sillam, E. (2001) Use of RAPD markers for the study of microbial community similarity from termite mounds and tropical soils. Soil Biology and Biochemistry, v. 33(4), pp. 417-427.

Holt, J.A. and Lepage, M. (2000) Termites and soil properties. In: T. Abe, D.E. Bignell and M. Higashi, (eds.) Termites: evolution, sociality, symbioses, ecology. Springer Netherlands, pp. 389-407.

Jackson, M.L. (1958) Soil chemistry analysis. Prentic-Hall Inc., Engelowood Cliffs.

Jouquet, P., Barré, P., Lepage, M. and Velde, B. (2005) Impact of subterranean fungus-growing termites (Isoptera, Macrotermitiane) on chosen soil properties in a West African savanna. Biology and Fertility of Soils, v. 41(5), pp. 365-370. 
Biological Weathering and Geochemical Fractionation by Termites: A Case Study of Loessic Sediments from Jawaharlal Nehru University, New Delhi, India: Singh et al.

Jouquet, P., Bottinelli, N., Lata, J.C., Mora, P. and Caquineau, S. (2007) Role of the fungus-growing termite Pseudacanthotermes spiniger (Isoptera, Macrotermitinae) in the dynamic of clay and soil organic matter content. An experimental analysis. Geoderma, v. 139(1), pp.127-133.

Jouquet, P., Dauber, J., Lagerlöf, J., Lavelle, P. and Lepage, M. (2006) Soil invertebrates as ecosystem engineers: intended and accidental effects on soil and feedback loops. Applied Soil Ecology, v. 32(2), pp.153-164.

Jouquet, P., Lepage, M. and Velde, B. (2002) Termite soil preferences and particle selections: strategies related to ecological requirements. Insectes Sociaux, v. 49(1), pp.1-7.

Jouquet, P., Mamou, L., Lepage, M. and Velde, B. (2002) Effect of termites on clay minerals in tropical soils: fungus-growing termites as weathering agents. European Journal of Soil Science, v. 53(4), pp.521-528.

Kappler, A. and Brune, A. (1999) Influence of gut alkalinity and oxygen status on mobilization and sizeclass distribution of humic acids in the hindgut of soil-feeding termites. Applied Soil Ecology, v. 13(3), pp. 219-229.

Klaus, G., Klaus-Hügi, C. and Schmid, B. (1998) Geophagy by large mammals at natural licks in the rain forest of the Dzanga National Park, Central African Republic. Journal of Tropical Ecology, v. 14(06), pp. 829-839.

Lavelle, P. (1997) Faunal activities and soil processes: adaptive strategies that determine ecosystem function. Advances in Ecological Research, v. 27, pp. 93-132.

Lee, K.E. and Wood, T.G. (1971) Termites and soils. London, UK, Academic Press.

Liu, X., Monger, H.C. and Whitford, W.G. (2007) Calcium carbonate in termite galleries-biomineralization or upward transport? Biogeochemistry, v. 82(3), pp. 241-250.

Mahaney, W.C., Zippin, J., Milner, M.W., Sanmugadas, K., Hancock, R.G.V., Aufreiter, S., Campbell, S., Huffman, M.A., Wink, M., Malloch, D. and Kalm, V. (1999) Chemistry, mineralogy and microbiology of termite mound soil eaten by the chimpanzees of the Mahale Mountains, Western Tanzania. Journal of Tropical Ecology, v. 15(05), pp. 565-588.

Milewski, A.V. and Diamond, R.E. (2000) Why are very large herbivores absent from Australia? A new theory of micronutrients. Journal of Biogeography, v. 27(4), pp. 957-978.

Mills, A.J., Milewski, A., Fey, M.V., Groengroeft, A. and Petersen, A. (2009) Fungus culturing, nutrient mining and geophagy: a geochemical investigation of Macrotermes and Trinervitermes mounds in southern Africa. Journal of Zoology, v. 278(1), pp. 24-35.

Mishra, A., Tripathi, J.K., Mehta, P. and Rajamani, V. (2013) Phosphorus distribution and fractionation during weathering of amphibolites and gneisses in different climatic setups of the Kaveri river catchment, India. Applied geochemistry, v. 33, pp.173-181.

Mujinya, B.B., Mees, F., Boeckx, P., Bodé, S., Baert, G., Erens, H., Delefortrie, S., Verdoodt, A., Ngongo, M. and Van Ranst, E. (2011) The origin of carbonates in termite mounds of the Lubumbashi area, DR Congo. Geoderma, v. 165(1), pp. 95-105.

Mujinya, B.B., Mees, F., Erens, H., Dumon, M., Baert, G., Boeckx, P., Ngongo, M. and Van Ranst, E. (2013) Clay composition and properties in termite mounds of the Lubumbashi area, DR Congo. Geoderma, v. 192, pp. 304-315.

Mujinya, B.B., Van Ranst, E., Verdoodt, A., Baert, G. and Ngongo, L.M. (2010). Termite bioturbation effects on electro-chemical properties of ferralsols in the Upper Katanga (DR Congo). Geoderma, v. 158(3), pp. 233-241. 
Biological Weathering and Geochemical Fractionation by Termites: A Case Study of Loessic Sediments from Jawaharlal Nehru University, New Delhi, India: Singh et al.

Nesbitt, H.W. and Young, G.M. (1984) Prediction of some weathering trends of plutonic and volcanic rocks based on thermodynamic and kinetic considerations. Geochimica et Cosmochimica Acta, v. 48(7), pp.1523-1534.

Nesbitt, H.W. and Young, G.M. (1989) Formation and diagenesis of weathering profiles. Journal of Geology, v. 97(2), pp.129-147.

Ohkuma, M. (2003) Termite symbiotic systems: efficient bio-recycling of lignocellulose. Applied Microbiology and Biotechnology, v. 61(1), pp.1-9.

Pandarinath, K. (2003) Identification and quantification of clay and other minerals. In: One day worshop on X-Ray diffraction studies on Clays, $14^{\text {th }}$ Jan. 2003, Ocean Science and Technology Cell, Mangalore University, pp. 50-56.

Pathak, A. K., Yadav, S., Kumar, P. and Kumar, R. (2013) Source apportionment and spatial-temporal variations in the metal content of surface dust collected from an industrial area adjoining Delhi, India. Science of the Total Environment, v. 443, pp. 662-672.

Sako, A., Mills, A.J. and Roychoudhury, A.N. (2009) Rare earth and trace element geochemistry of termite mounds in central and northeastern Namibia: Mechanisms for micro-nutrient accumulation. Geoderma, v. 153(1), pp. 217-230.

Semhi, K., Chaudhuri, S., Clauer, N. and Boeglin, J.L. (2008) Impact of termite activity on soil environment: A perspective from their soluble chemical components. International Journal of Environmental Science \& Technology, v. 5(4), pp. 431-444.

Tripathi, J.K. and Rajamani, V. (1999) Geochemistry of the loessic sediments on Delhi ridge, eastern Thar desert, Rajasthan: implications for exogenic processes. Chemical Geology, v. 155(3), pp. 265-278.

Tripathi, J.K. and Rajamani, V. (2003) Geochemistry of Proterozoic Delhi quartzites: Implications for the provenance and source area weathering. Geological Society of India, v. 62(2), pp. 215-226.

Tripathi, J.K., Ghazanfari, P., Rajamani, V. and Tandon, S.K. (2007) Geochemistry of sediments of the Ganges alluvial plains: evidence of large-scale sediment recycling. Quaternary International, v. 159(1), pp.119-130.

Walkley, A. (1947) A critical examination of a rapid method for determining organic carbon in soils- effect of variations in digestion conditions and of inorganic soil constituents. Soil Science, v. 63(4), pp. 251-264.

Watson, J.P. (1975) The composition of termite (Macrotermes spp.) mounds on soil derived from basic rock in three rainfall zones of Rhodesia. Geoderma, v. 14(2), pp.147-158.

(Received: 20.05.2017; Accepted: 20.07.2017) 